\title{
Spatial associations between large baleen whales and their prey in West Greenland
}

\author{
Kristin L. Laidre ${ }^{1,2, *}$, Mads Peter Heide-Jørgensen², Patrick Heagerty ${ }^{3}$, \\ Anthony Cossio ${ }^{4}$, Bo Bergström ${ }^{2}$, Malene Simon ${ }^{2,5}$ \\ ${ }^{1}$ Polar Science Center, Applied Physics Laboratory, University of Washington, 1013 NE 40th Street, Seattle, \\ Washington 98105, USA \\ ${ }^{2}$ Greenland Institute of Natural Resources, Box 570, 3900 Nuuk, Greenland \\ ${ }^{3}$ Department of Biostatistics, University of Washington, Seattle, Washington, USA \\ ${ }^{4}$ Southwest Fisheries Science Center, 3333 North Torrey Pines Road, La Jolla, California, USA \\ ${ }^{5}$ Department of Biological Sciences, University of Aarhus, C.F. Møllers Allé, 8000 Aarhus, Denmark
}

\begin{abstract}
This study combined data on fin whale Balaenoptera physalus, humpback whale Megaptera novaeangliae, minke whale B. acutorostrata, and sei whale B. borealis sightings from large-scale visual aerial and ship-based surveys (248 and 157 sightings, respectively) with synoptic acoustic sampling of krill Meganyctiphanes norvegica and Thysanoessa sp. abundance in September 2005 in West Greenland to examine the relationships between whales and their prey. Krill densities were obtained by converting relationships of volume backscattering strengths at multiple frequencies to a numerical density using an estimate of krill target strength. Krill data were vertically integrated in $25 \mathrm{~m}$ depth bins between 0 and $300 \mathrm{~m}$ to obtain water column biomass $\left(\mathrm{g} \mathrm{m}^{-2}\right)$ and translated to density surfaces using ordinary kriging. Standard regression models (Generalized Additive Modeling, GAM, and Generalized Linear Modeling, GLM) were developed to identify important explanatory variables relating the presence, absence, and density of large whales to the physical and biological environment and different survey platforms. Large baleen whales were concentrated in 3 focal areas: (1) the northern edge of Lille Hellefiske bank between 65 and $67^{\circ} \mathrm{N}$, (2) north of Paamiut at $63^{\circ} \mathrm{N}$, and (3) in South Greenland between 60 and $61^{\circ} \mathrm{N}$. There was a bimodal pattern of mean krill density between depths, with one peak between 50 and $75 \mathrm{~m}$ (mean $0.75 \mathrm{~g} \mathrm{~m}^{-2}$, SD 2.74) and another between 225 and $275 \mathrm{~m}$ (mean 1.2 to $1.3 \mathrm{~g} \mathrm{~m}^{-2}$, SD 23 to19). Water column krill biomass was 3 times higher in South Greenland than at any other site along the coast. Total depth-integrated krill biomass was $1.3 \times 10^{9}(\mathrm{CV}$ 0.11). Models indicated the most important parameter in predicting large baleen whale presence was integrated krill abundance, although this relationship was only significant for sightings obtained on the ship survey. This suggests that a high degree of spatio-temporal synchrony in observations is necessary for quantifying predator-prey relationships. Krill biomass was most predictive of whale presence at depths $>150 \mathrm{~m}$, suggesting a threshold depth below which it is energetically optimal for baleen whales to forage on krill in West Greenland.
\end{abstract}

KEY WORDS: Baleen whale $\cdot$ Capelin $\cdot$ Greenland $\cdot$ Krill $\cdot$ Nautical Area Scattering Coefficient · NASC $\cdot$ Optimal foraging $\cdot$ Survey

\section{INTRODUCTION}

The shelf ecosystems of the Arctic contain some of the most productive and tightly connected physicalbiological systems in the marine environment. These relatively shallow domains play an important role in inflow and outflow from the Arctic Ocean, sea ice dynamics, and energy transfer through the ecosystem (Carmack \& Wassmann 2006). Arctic continental shelves tend to accumulate large biomass concentrations either through seasonally restricted but intense production blooms or by local accumulation of biomass via advection. 
The coastline of West Greenland is the longest continuous stretch of sub-Arctic to Arctic coastline in the world (Laidre et al. 2008). When the annual winter sea ice cover retreats, it triggers an enormous bloom of primary production on the shelf, attracting high densities of lower trophic level forage fish and zooplankton (Heide-Jørgensen et al. 2007a) ultimately culminating in large numbers of top marine predators. At least 10 species of cetaceans move in from the North Atlantic to take advantage of the explosion in production on the banks. Four of these, the fin whale Balaenoptera physalus, humpback whale Megaptera novaeangliae, minke whale $B$. acutorostrata, and sei whale $B$. borealis are the most abundant of the sub-Arctic baleen whales that migrate to the waters of West Greenland.

Optimal foraging theory suggests predators optimize their foraging behavior in patchy habitats to maximize fitness (Schoener 1971, Charnov 1976). Piatt \& Methven (1992) examined this in baleen whales and suggested that a threshold prey density is required to facilitate foraging, and that seasonal and annual variations in prey densities play a role in the aggregation of whales and foraging profitability. In West Greenland, few data are available on the densities and spatial distribution of forage fish and zooplankton targeted by baleen whales (Kapel 1979) mostly because the area is vast and few large-scale prey surveys exist concurrent with cetacean sighting surveys. Based on stomach content analysis and visual observations (Kapel 1979), primary prey species for large whales are known to be krill, capelin Mallotus villosus, and to a lesser extent sandeel Ammodytidae spp., However, there is a limited understanding of how the distribution of whales in West Greenland is related to spatial and temporal variation in patchy resources (Heide-Jørgensen \& Laidre 2007). These are important topics in light of changes in sea temperatures, sea currents, and biological production in the ecosystem due to climate warming (Myers et al. 2007). Furthermore, both fin and minke whales in West Greenland are subject to an annual subsistence harvest (Laidre et al. 2009), and understanding the dynamics of ecological relationships is critical.

The recent advancement of acoustic methods for assessing the abundance of prey species (Conti et al. 2005a,b, Conti \& Demer 2006), combined with visual aerial survey techniques for estimating cetacean distribution and abundance, facilitate in-depth analyses of spatial relationships (Friedlaender et al. 2006). In this study, information from large-scale visual surveys of baleen whales and synoptic acoustic sampling of krill and capelin abundance in West Greenland were combined to examine quantitative spatial relationships between whales and their prey. We report on the distribution of the 4 whale species on the shelf of West Greenland and develop a series of statistical models relating whale occurrence to a suite of variables describing the physical environment and their prey. It was hypothesized that large whale occurrence and densities would be positively correlated with krill abundance over the survey area given the importance of the West Greenland shelf area for top predator feeding in summer.

\section{MATERIALS AND METHODS}

Ship survey data collection. Between 2 September and 3 October 2005 a systematic acoustic survey targeting capelin was conducted on the West Greenland shelf from the Icelandic fisheries research vessel RV 'Bjarni Saemundsson.' The survey was designed to cover the area between the coast and shelf break (up to $100 \mathrm{~km}$ offshore). Transect lines were placed in an east-west direction with 22 nautical mile (n mile) spacing and beginning approximately $3 \mathrm{n}$ miles from the coast continuing west to the $400 \mathrm{~m}$ isobath. The survey began in the north and progressed south, including Vaigat, Disko Bay, and 5 fjords including Nuuk fjord (Fig. 1)

Acoustic data were collected continuously with a Simrad EK 60 echosounder at 38 and $120 \mathrm{kHz}$ with $1 \mathrm{~ms}$ pulse duration and inter-pulse intervals of $1 \mathrm{~s}$. Transducers were hull-mounted $5 \mathrm{~m}$ below the waterline. Echograms were used to estimate the abundance of capelin Mallotus villosus and krill Meganyctiphanes norvegica and Thysanoessa sp. Identification of observed sound-scattering organisms were groundtruthed by targeted pelagic trawl and plankton net hauls.

Simultaneous visual observations of large whales were conducted aboard the research vessel (HeideJørgensen et al. 2007b). Four cetacean observers scanned the water on either side of the vessel in pairs from an observation platform each covering 90 degrees in front of the vessel with an observer eye height of $10.3 \mathrm{~m}$ above sea level. The observers only used binoculars for species identification after recording a whale sighting. On-effort observations were carried out during all hours of daylight when weather conditions permitted (sea state less than 6 and visibility more than $500 \mathrm{~m}$ ). Positional information was obtained with a handheld or onboard GPS. Sightings of whales from the ship-based survey were converted into abundance estimates using standard line transect techniques (see Heide-Jørgensen et al. 2007b for abundance estimates). The sea surface temperature was measured continuously along the ship track every minute.

Aerial survey data collection. A concurrent visual aerial survey for large whales was conducted between 


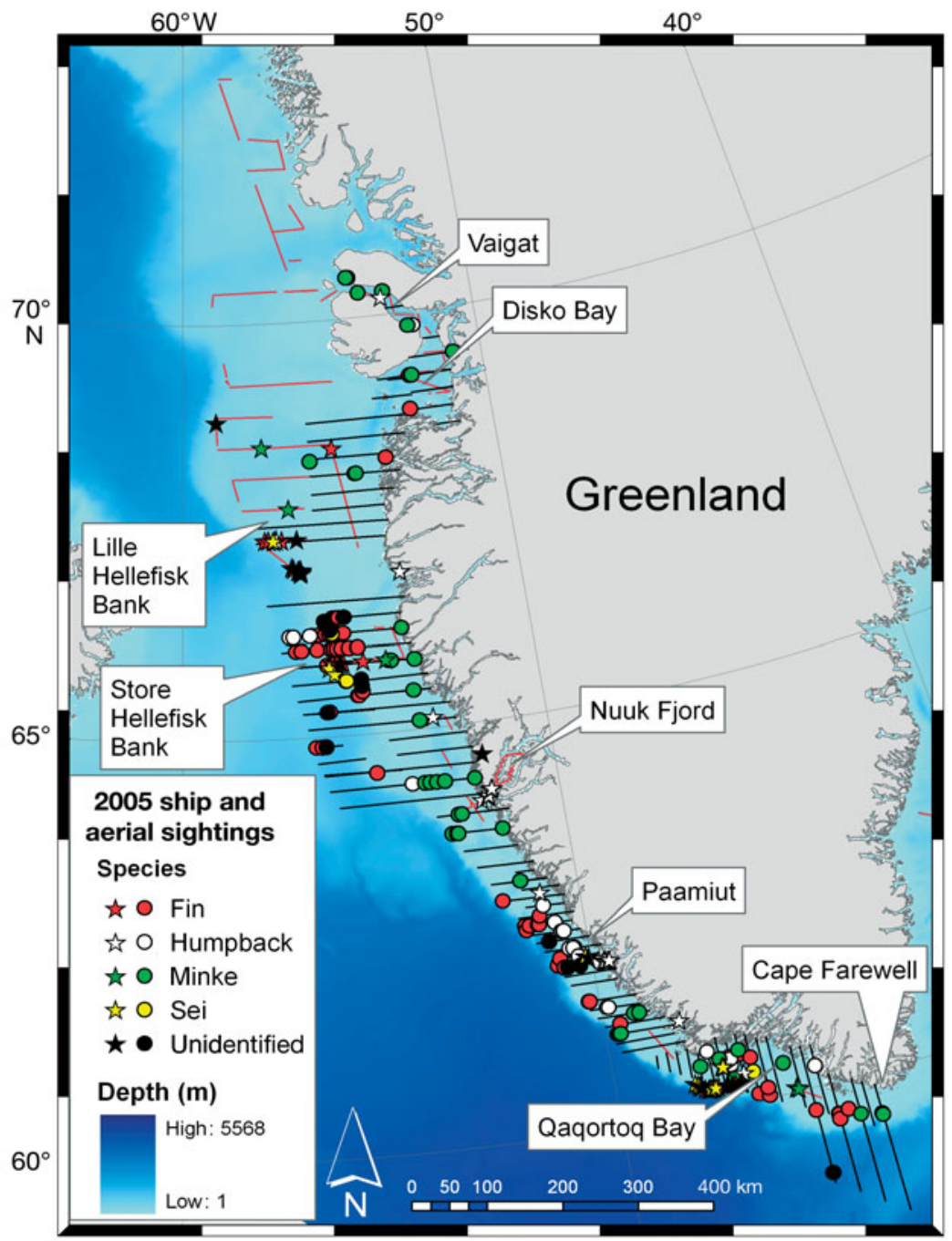

Fig. 1. Map of aerial and ship survey on-effort tracklines together with sightings of large baleen whale species in West Greenland. Ship survey effort is in red and aerial survey effort is in black. Note some survey lines overlap. Symbol colors represent different species sightings with ship survey sightings denoted by a star and aerial survey sightings denoted by a circle

zontal visibility, or glare occurred. The survey was designed to systematically cover the coast of West Greenland offshore to the shelf break (i.e. $200 \mathrm{~m}$ depth contour). Transect lines were placed perpendicular to the coast (i.e. in an east-west direction) except for South Greenland, where they were placed in a north-south direction (Fig. 1). Sightings of whales from the aerial survey were converted into abundance estimates using standard line transect and cue-counting techniques (see Heide-Jørgensen et al. 2008).

Acoustic analysis for krill abundance. Krill data were processed in $25 \mathrm{~m}$ depth bins at a spatial resolution of $1 \mathrm{n}$ mile between daily sunrise and sunset. Data collected during nighttime or when the ship paused for CTD stations were excluded. Night data were excluded to minimize the bias of diel vertical migration of krill (Onsrud \& Kaartvedt 1998) and data collected during CTD stations were excluded to reduce oversampling of krill at speeds under 2 knots. Relationships of volume backscattering strengths $\left(S_{v i} \mathrm{~dB}\right.$ re 1 $\mathrm{m}^{-1}$ ) measured at multiple frequencies were used to apportion the integrated volume backscattering coefficients (Nautical Area Scattering Coefficient, NASC $; \mathrm{m}^{2} \mathrm{n}$ mile $^{-2}$ ) to krill versus other fish backscatter (see Hewitt et al. 2003, Riess et al. 2008), before converting NASC to a numerical density using an estimate of krill target strength (TS; dB re $1 \mathrm{~m}^{2}$ ).

$S_{V}$ at both frequencies was averaged over $25 \mathrm{~m}$ depth bins and $100 \mathrm{~s}$. Back-

28 August and 23 September 2005 (Heide-Jørgensen et al. 2008) in the same area. The survey platform was an Icelandic Partenavia Observer P-68 with 2 observers located in the rear seats each with bubble windows. An additional observer/cruise leader was seated in the right front seat. Declination angle to sightings was measured with Suunto inclinometers, and the lateral angle from the nose of the aircraft was estimated. Sightings were entered on dictaphones and on a computer-based voice recording system that also logged the position of the plane (from the aircraft GPS). Target altitude and speed was 750 feet $(229 \mathrm{~m})$ and 90 knots $\left(167 \mathrm{~km} \mathrm{~h}^{-1}\right)$, respectively.

Survey conditions were recorded at the start of the transect lines and whenever a change in sea state, horiground noise was subtracted and the $S_{V}$ at $120 \mathrm{kHz}$ $\left(S_{V 120} \mathrm{kHz}\right)$ was apportioned into regions of krill versus non-krill using a 2-frequency algorithm (see Madureria et al. 1993, Hewitt et al. 2003 for details). $S_{V 120} \mathrm{kHz}$ attributed to krill was integrated from $10 \mathrm{~m}$ below the surface (to exclude surface noise) to either a maximum of $500 \mathrm{~m}$ or approximately $5 \mathrm{~m}$ above the seafloor, resulting in NASC at $1 \mathrm{n}$ mile increments. A $\Delta S_{V}$ range for 120 to $38 \mathrm{kHz}$ of 4.6 to $11.1 \mathrm{~dB}$ was used for the delineation of krill from other backscatter based on length frequencies (CCAMLR 2005) for both Euphausia superba and Meganyctiphanes norvegica (Conti et al. 2005a,b).

The NASC were converted to biomass densities $\left(\mathrm{g} \mathrm{m}^{-2}\right)$ using the simplified version of the Stochastic 
Distorted Wave Born Approximation (SDWBA) model (Conti \& Demer 2006). A normal distribution of orientations was used to derive the simplified SDWBA $\left(\theta=\mathrm{N}\left[\right.\right.$ mean $\left.\left.=11^{\circ}, \mathrm{SD}=4^{\circ}\right]\right)$, estimated from an inversion of the SDWBA model using $S_{V}$ measurements at multiple frequencies. The simplified SDWBA model required distributions of krill total lengths (TL or length-probability density functions [pdfs]) to derive weighted-mean backscattering cross-sectional areas per whale $\left(=4 \pi 10^{\mathrm{TS} / 10}\right.$; where TS is target strength, $\mathrm{m}^{2} \mathrm{krill}^{-1}$; Demer \& Hewitt 1995). Likewise, krill length-pdfs were needed to calculate weightedmean masses per individual ( $W_{i} \mathrm{~g} \mathrm{krill}^{-1}$ ) from appropriate mass-to-length relationships. This was based on net haul samples collected during the survey, calculated as:

$$
W=2.31 \times 10^{-2} \times \mathrm{TL}^{2.6976}
$$

Dividing NASC by $\sigma\left(\sigma=4 \pi \mathrm{r} 10^{\mathrm{TS} / 10}\right.$ where $\mathrm{r}$ is the reference range of $1 \mathrm{~m}$ ) yields the number density ( $\rho ; \mathrm{N} \mathrm{n}$ mile ${ }^{-2}$ ) and multiplying $\rho$ by $W$ yields the biomass density $\left(\mathrm{g} \mathrm{m}^{-2}\right)$. Krill biomass estimates were vertically integrated in $25 \mathrm{~m}$ incremental depth bins between 0 and $300 \mathrm{~m}$ (or 12 bins) to obtain water column krill biomass $\left(\mathrm{g} \mathrm{m}^{-2}\right)$. Total integrated water column krill biomass (kg) in the study area was also estimated using a stratified sampling approach in the 5 geographic strata corresponding to whale abundance estimates from the ship-based survey reported in Heide-Jørgensen et al. (2007b).

Spatial data analysis. The Geographic Information System (GIS; ESRI Arc9) was used to make spatial associations between the location of cetacean sightings and a suite of environmental variables. The analysis was restricted to West Greenland waters and all data north of Cape Farwell (southern tip of Greenland located at $43.5^{\circ} \mathrm{W}$ longitude). The standard projection was Polar Stereographic (in $\mathrm{m}$ ) with a central meridian of $55^{\circ} \mathrm{W}$ and reference latitude of $75^{\circ} \mathrm{N}$. Coastline data for Greenland were obtained from the US Defense mapping agency as part of the World Vector Shoreline (WVS) at a scale of 1:250 000, referenced to mean high water in a datum of WGS84. Spatial bathymetric data were obtained from the International Bathymetry Chart of the Arctic Ocean (IBCAO, www.ibcao.org) (Jakobsson et al. 2008) with a $2 \mathrm{~km}$ resolution. This resolution was selected so that there was consistency in other remotely sensed and GIS covariates in the model. A categorical variable depth grid was also created with 3 depth categories: 0 to $500 \mathrm{~m}$ (shelf), 500 to $1500 \mathrm{~m}$ (slope), 1500 to $2300 \mathrm{~m}$ (deep). Sea-floor slope was calculated as integer value of the percent rise between adjacent bathymetry grid cells and classified into one of 4 categories, as follows: 0,1 to 2,3 to 4 , and $\geq 5 \%$ rise.
Point samples of sea surface temperature were used to create a continuous surface using a spherical ordinary kriging model based on a sub-sample of temperature values every 5 min (7160 data points) (temperature was collected every $1 \mathrm{~min}$ on the trackline). Kernel probability contours were calculated for each of the 4 baleen whale species sightings and for all species pooled together in 50, 75 and $95 \%$ probability contours.

Statistical analysis. Vertically integrated water column krill biomass $\left(\mathrm{g} \mathrm{m}^{-2}\right)$ in $25 \mathrm{~m}$ depth increments and between 0 and $300 \mathrm{~m}$ was calculated every $\mathrm{n}$ mile. These point-based biomass estimates were translated to density surfaces for each depth increment using an ordinary kriging approach implemented in the ArcGIS Geostatistical Analyst extension. Kriging, a statistical approach suitable for representing interpolated surfaces for phenomena with strong random components (Pople et al. 2007), was best achieved with a spherical model fitted to the semi-variogram for each krill depth bin with no trend removal. A $45^{\circ}$ search angle to the survey lines appeared to be optimal, capturing along- and between-survey line variability. Interpolated surfaces were restricted to the surveyed area (Fig. 1).

The spatial analysis examined the presence/absence or density of whales per unit (cell). The spatial analysis was conducted on a spatial resolution of $2 \mathrm{~km}$. Four species were considered in the analysis: fin whales, sei whales, humpback whales, and minke whales. Sightings of large groups of humpbacks were truncated into categories of $\geq 30$ animals and for fin whales $\geq 10$ animals. We also included 3 species 'groups' in the models: all species pooled, all positively identified large baleen whales (fin, sei and humpback), and all unidentified large whales (excluding minkes).

The sightings and the effort from the ship and aerial surveys were combined into one model. We used all baleen whale sightings in sea states $\leq 6$ on the ship survey, and $\leq 4$ on the aerial survey. These criteria were modified slightly for the inclusion of minke whale sightings, where only sightings where sea state was $\leq 2$ on the ship survey and $\leq 3$ during the aerial survey were included. For the statistical modeling, it was necessary to obtain representative coverage of where whales were absent. We randomly sampled 5000 locations along both the ship and aerial trackline where no whale sightings were made. This represented over 20 times the number of whale sightings that occurred in the study area.

Input data for statistical models were whale sightings, randomly selected real absence locations, and GIS variables describing conditions hypothesized to determine whale presence/absence and density (group size). These included survey type (aerial vs. 
ship), sea surface temperature $\left({ }^{\circ} \mathrm{C}\right)$, latitude, longitude, krill water column biomass in $\left(\mathrm{g} \mathrm{m}^{-2}\right)$ in $25 \mathrm{~m}$ depth increments and total integrated biomass, seafloor depth (m), and seafloor slope (\% rise).

In order to evaluate whether data could be pooled from the 2 survey types (ship and aerial) we conducted both pooled and separate analyses on each data set and formally tested whether covariate effects differed by modality. We tested for significance of interactions by modality for each of the covariates.

Standard regression models were developed using the open-source statistical package R (R Development Core Team 2009). Models identified important explanatory variables relating the presence/absence and density of large whales to the physical and biological environment. We modeled the probability of whale occurrence as a function of environmental variables using Generalized Additive Modeling (GAM), where response variables were modeled as a smoothed function of all explanatory variables using nonparametric regression procedures. Standard GAM software was used descriptively to characterize trends. Inference about specific regression coefficients was made using a variation of Generalized Estimating Equations (GEE) and either logistic or Poisson regression while accounting for spatial autocorrelation (Heagerty \& Lumley 2000). Due to colinearity between latitude and longitude, we transformed longitude to a new variable (res.long), which was the residual longitude after regression of longitude on latitude. This variable represented the east-west variation within the latitude. Based on covariate trends observed in the GAM analysis, all covariates were approximately linearly related to the outcome with the exception of latitude, which was modeled using both linear and quadratic terms. Significance was determined at the 0.05 level.

Depth-specific regressions were made on krill abundance at each depth interval to predict the probability (Pr) of a sighting using the following regression equation:

$\operatorname{Logit}(\operatorname{Pr}[y=1])=b_{0}+b_{1}(d) \times \log [$ Abundance $(d)]+b_{2} \times$ Latitude $+b_{3} \times$ Latitude $^{2}+b_{4} \times$ res.long $+b_{5} \times$ Depth + $b_{6} \times$ Temperature $+b_{7} \times$ Slope

In this regression model the coefficient $b_{1}(d)$ represented the association between the likelihood of a sighting and the krill abundance measured at depth bin $d$. Since we considered depth bins ranging from 0 $\mathrm{m}$ up to $300 \mathrm{~m}$ at $25 \mathrm{~m}$ increments, we estimated 12 different depth-specific coefficients. Specifically, the slope coefficient $b_{1}(d)$ measured the increase in the risk of a sighting (log odds of any sighting) as the $\log [$ Abundance $(d)]$ increased by 1 unit.

\section{RESULTS}

\section{Baleen whale distribution}

During the ship and aerial surveys 248 on-effort sightings of baleen whales were collected (Fig. 1). Search effort on both surveys was interrupted by nights and bad weather; however, $9266 \mathrm{~km}$ of survey effort was conducted during both surveys combined.

During the aerial portion, 157 sightings were made during $6458 \mathrm{~km}$ of on-effort searching. Of these, 78 were fin whales, 21 were humpback whales, 42 were minke whales, and 4 were sei whales. There were also 12 sightings of unidentified large baleen whales (Fig. 2, Table 1). During the ship portion, 91 sightings were made during $2808 \mathrm{~km}$ of on-effort. Of these, 30 sightings were from fin whales, 26 were humpback whales, 6 were minke whales, and 13 were sei whales. Additionally 16 sightings of unidentified large baleen whales were made (Fig. 2, Table 1). Group sizes were for the most part not larger than 10 with the exception of a few exceptionally large groups of fin and humpback whales on the aerial survey. This included groups as large as 95 humpback whales (Fig. 3) and 50 fin whales. Detailed documentation of sighting distribution and abundances of all species are reported in HeideJørgensen et al. (2007b, 2008).

Fin whales were the most common large whale sighted during both surveys ( $\mathrm{n}=108$ sightings) and were found in high densities between the Store and Lille Hellefiske banks and off Paamiut. South Greenland was the area with the largest group sizes; 3 groups of 10 to 13 individual fin whales and one group of 50 individuals were observed at $60^{\circ} \mathrm{N}, 47^{\circ} \mathrm{W}$ (Fig. 2a). Humpback whale sightings $(\mathrm{n}=47)$ were distributed along the coast with most sightings occurring nearshore and primarily in South Greenland. Five large groups of humpbacks (>25 individuals, with one group of $>95$ individuals) were observed south of $62^{\circ} \mathrm{N}$ (Fig. 2b, Fig. 3). Minke whales ( $\mathrm{n}=48$ sightings) were broadly distributed along the coast and had the least clumped distribution of the 4 species. There was a hiatus in distribution between SW (Southwest) Greenland and CW (Central West) Greenland (see Fig. 5 for area designation) with no sightings observed between $62^{\circ}$ and $63^{\circ} \mathrm{N}$ (Fig. 2c). Several sightings of minke whales occurred in coastal waters of Vaigat and Disko Bay, areas with known high coastal capelin concentrations. Relatively few sightings of sei whales $(\mathrm{n}=17)$ were made on both surveys. Of those, sei whales were found in 2 specific areas: on the banks at $66^{\circ} \mathrm{N}$ at Lille Hellefiske Bank and in South Greenland at $60^{\circ} \mathrm{N}, 47^{\circ} \mathrm{W}$. Only one large group of 10 sei whales was seen (Fig. 2d). 


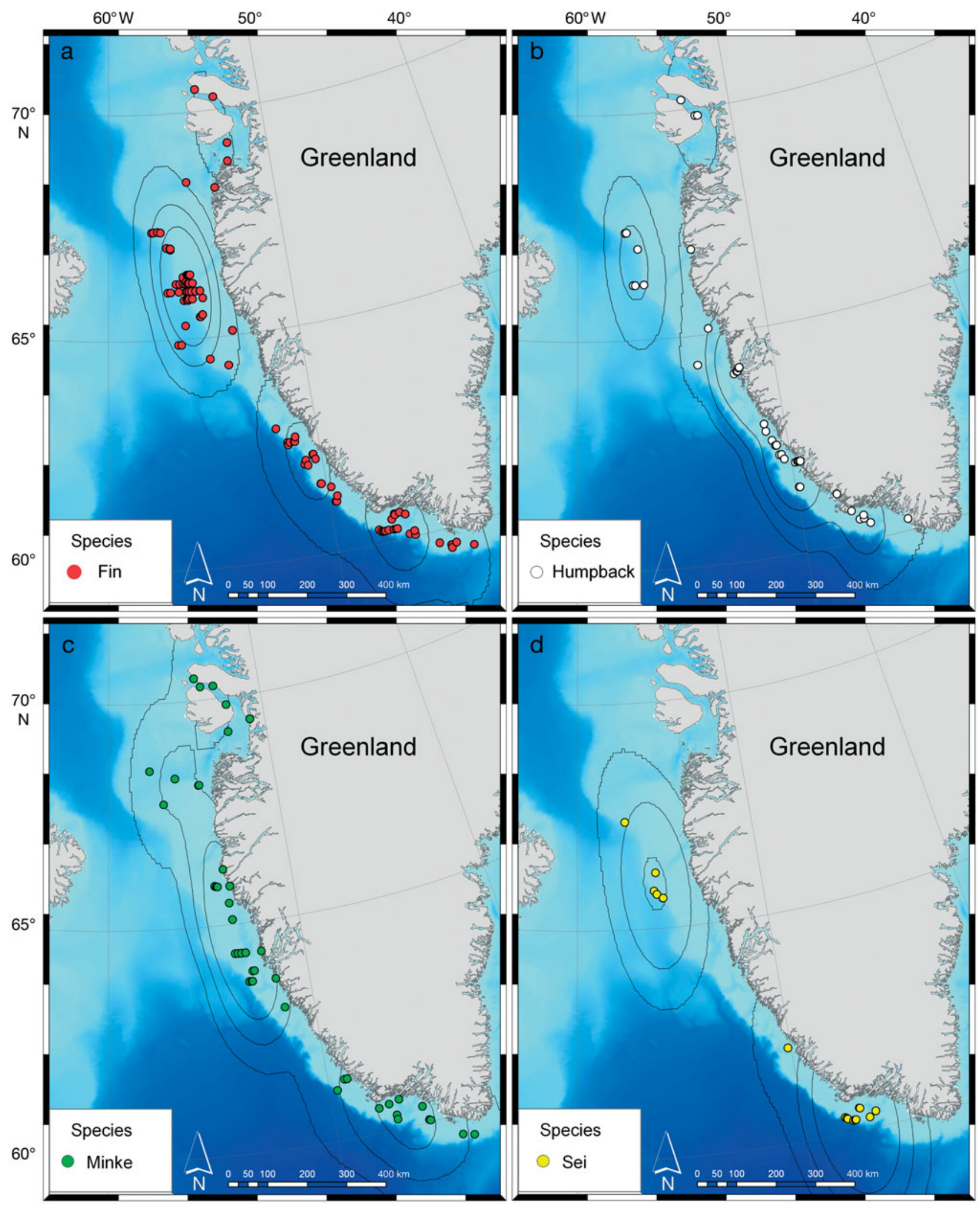

Fig. 2. Balaenoptera physalus, Megaptera novaeangliae, B. acutorostrata, and B. borealis. Distribution of sightings of 4 baleen whale species in West Greenland from ship and aerial surveys in 2005. Contour lines show approximate 50, 75 and $95 \%$ kernel contours 
Table 1. Sightings and group sizes (ind.) of baleen whales on aerial and ship surveys in West Greenland 2005

\begin{tabular}{|llcc|}
\hline Survey type & Species & $\begin{array}{c}\text { Number of } \\
\text { sightings }\end{array}$ & $\begin{array}{c}\text { Average group } \\
\text { size (range) }\end{array}$ \\
\hline Aerial & Fin & 78 & $3(1-50)$ \\
& Humpback & 21 & $17(1-95)$ \\
& Minke & 42 & $1(1-1)$ \\
& Sei & 4 & $3(1-10)$ \\
Ship & Unidentified & 12 & $1(1-3)$ \\
& Fin & 30 & $2(1-5)$ \\
& Humpback & 26 & $2(1-5)$ \\
& Minke & 6 & $1(1-2)$ \\
& Sei & 13 & $2(1-5)$ \\
& Unidentified & 16 & $1(1-2)$ \\
\hline
\end{tabular}

Overall, large baleen whales were concentrated in 3 focal areas along the coast of West Greenland: (1) the northern edge of Lille Hellefiske bank between $65^{\circ}$ and $67^{\circ} \mathrm{N}$, (2) north of Paamiut at $63^{\circ} \mathrm{N}$, and (3) in South Greenland between $60^{\circ}$ and $61^{\circ} \mathrm{N}$ in Qaqortoq Bay. (Fig. 4). The area with the highest density of whales was between $65^{\circ}$ and $67^{\circ} \mathrm{N}$, and sightings of all 4 species were made in this area.

\section{Capelin distribution}

The target species during the acoustic survey was capelin, and continuous acoustic sampling along the cruise trackline for this species was conducted (Fig. 5). Capelin were virtually absent on the banks over the entire survey area. They were, however, present in large numbers in all coastal fjords and nearshore areas between $70^{\circ}$ and $60^{\circ} \mathrm{N}$. The capelin biomass in these fjords and near shore areas was previously estimated to be between 170000 and 200000 metric tonnes (Bergström \& Vilhjalmarsson unpubl.). Capelin were excluded from the GAM analysis because of the highly discontinuous and coastal nature of their distribution, which made correlations with whale distribution on the offshore banks essentially impossible (Fig. 5).

\section{Krill distribution}

The mean density of krill $\left(\mathrm{g} \mathrm{m}^{-2}\right)$ was examined in $25 \mathrm{~m}$ depth increments along the coast of West Greenland (Fig. 5). There was a weakly bimodal pattern in

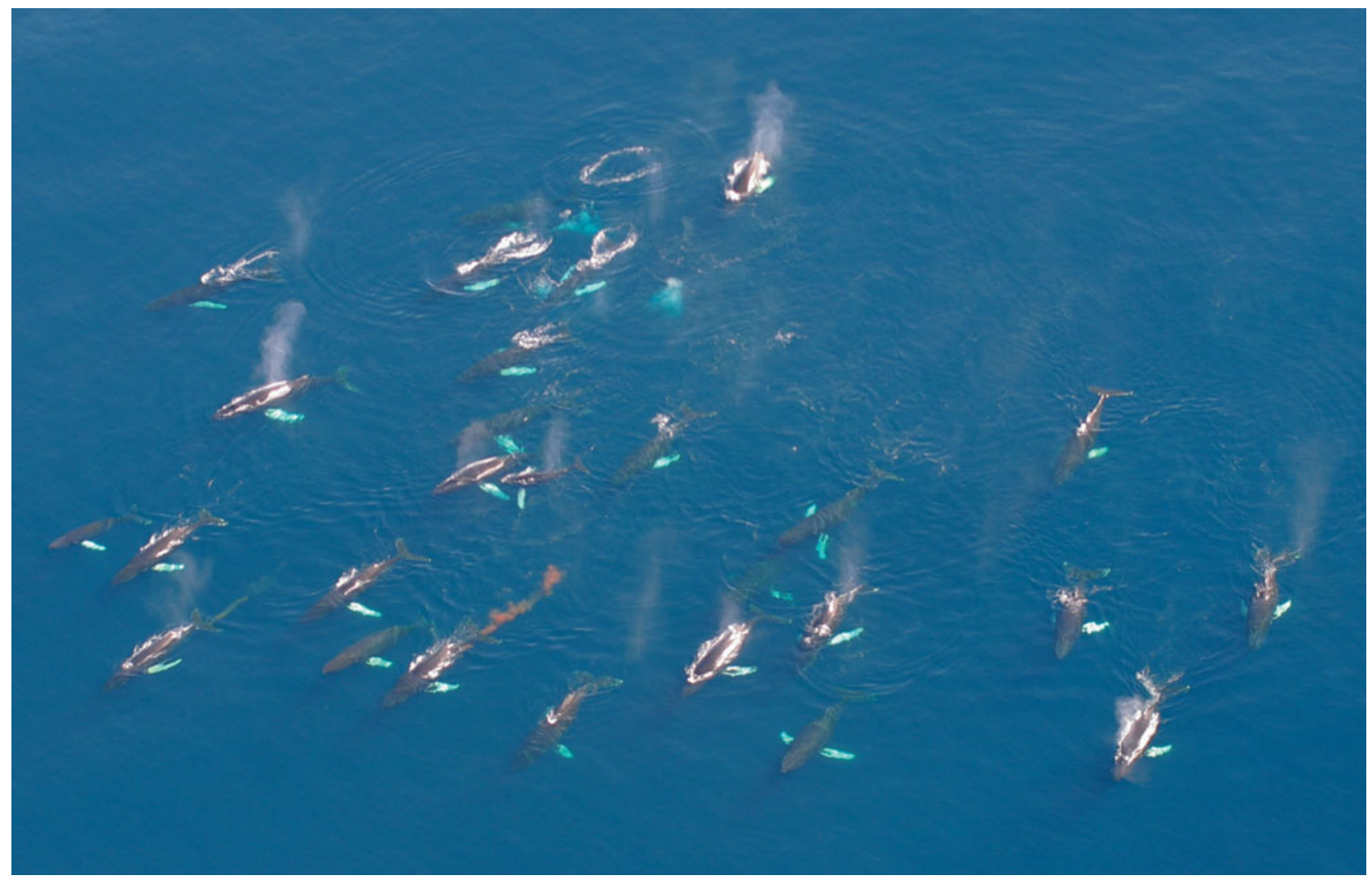

Fig. 3. Megaptera novaeangliae. Photo illustrating the exceptionally large group sizes of feeding humpback whales in West Greenland during the aerial survey conducted in 2005. Orange defecation is visible. Photos by Lars Witting 


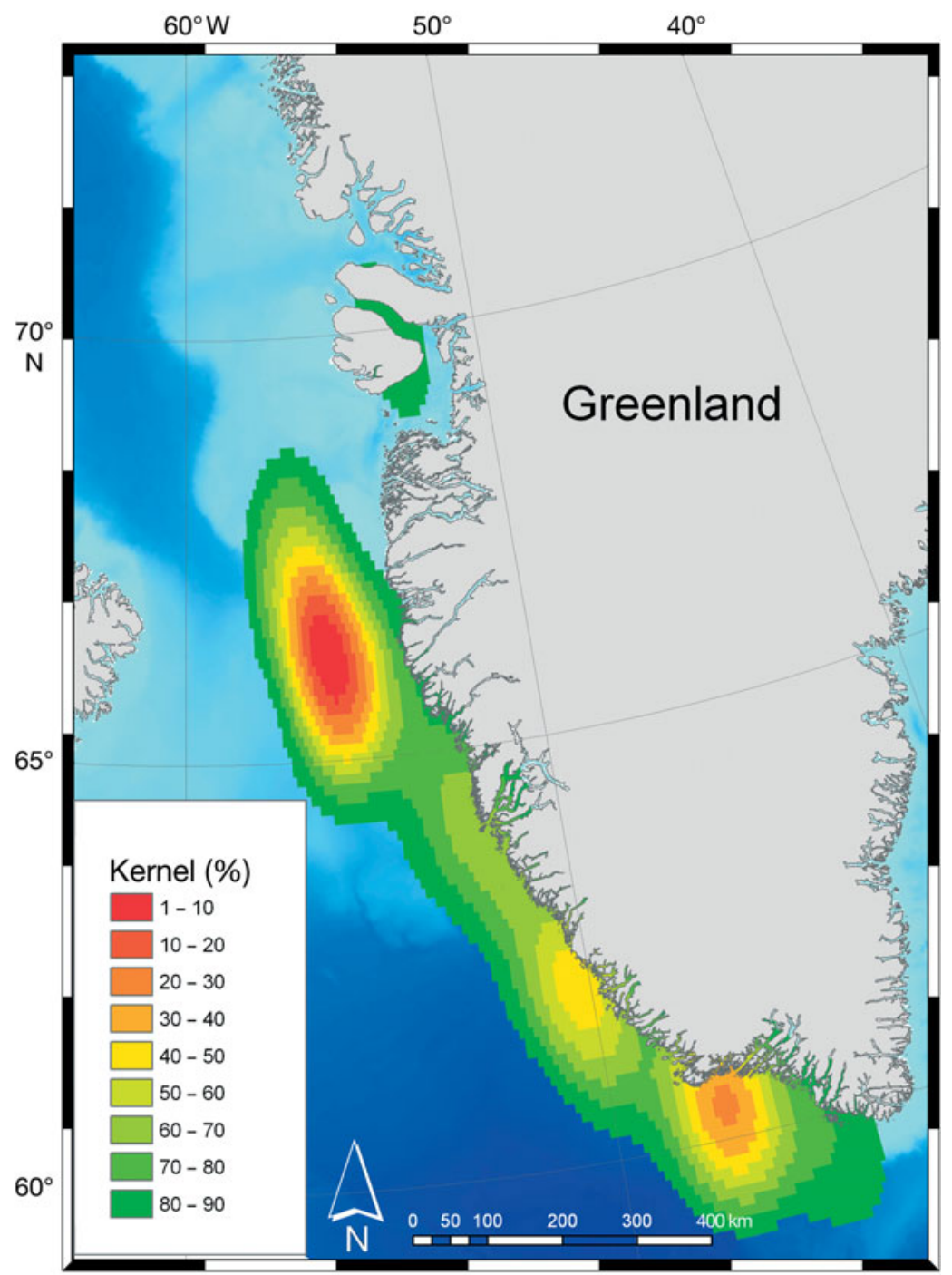

Fig. 4. Balaenoptera physalus, Megaptera novaeangliae, B. acutorostrata, and $B$. borealis. Kernel density estimation in $10 \%$ intervals for all sightings of large baleen whales from both ship and aerial surveys in 2005

found (>500 g m²) (Fig. 7), several orders of magnitude higher than all other measurements collected during the survey. This included 5 measurements of krill densities between 468 and $929 \mathrm{~g} \mathrm{~m}^{-2}$ (150 and $\left.300 \mathrm{~m}\right)$, suggesting very dense but patchy aggregations. Large but less extreme values of krill density (160 to $165 \mathrm{~g} \mathrm{~m}^{-2}$ ) were also detected at $66^{\circ} \mathrm{N}$, suggesting dense aggregations at these latitudes.

Integrated water column biomass of krill was estimated for each of 5 strata on the ship survey (Fig. 5). Highest densities of krill were found in the southwest strata (12.29 $\mathrm{g} \mathrm{m}^{-2}$, SD 0.16) and in Nuuk fjord (11.13 $\mathrm{g} \mathrm{m}^{-2}$, SD 0.4) (Fig. 5), consistent with the high densities of whales in South Greenland. Total biomass in the whole survey area was estimated as $1.3 \times 10^{9} \mathrm{~kg}$ of krill (CV 0.11), with the highest strata biomass found in SW Greenland (Table 2).

\section{Spatial analysis}

The complete model for large baleen whale presence on the West Greenland shelf included survey type and an interaction between integrated krill abundance and survey type (Table 3). This model suggested an observer was less likely to make a whale sighting on the ship. However, the interaction between survey platform and log of krill abundance was highly significant $(\mathrm{p}<$ 0.001). In separate models for each survey platform, the ship sighting data were strongly and positively correlated

mean krill density between 0 and $250 \mathrm{~m}$. The first peak occurred between 50 and $75 \mathrm{~m}$ with mean values of $0.75 \mathrm{~g} \mathrm{~m}^{-2}$ (SD 2.74) and the second between 225 and $275 \mathrm{~m}$ with mean values of 1.2 to $1.3 \mathrm{~g} \mathrm{~m}^{-2}$ (SD 23 to 19). As depths increased past $250 \mathrm{~m}$, mean krill density declined and was negligible by $500 \mathrm{~m}$ (Fig. 6). A striking pattern was the large aggregations of krill between 175 and $275 \mathrm{~m}$ (Fig. 6).

There was no correlation between mean krill density and latitude; however, density was 3 times higher at $60^{\circ} \mathrm{N}$ in South Greenland than at any other site along the coast (3.5 $\mathrm{g} \mathrm{m}^{-2} \mathrm{SD} 32$ ). Mean krill density was $<0.5$ $\mathrm{g} \mathrm{m}^{-2}$ at all latitudes with the exception of 2 small peaks at $63^{\circ}$ and $66^{\circ} \mathrm{N}\left(<1.5 \mathrm{~g} \mathrm{~m}^{-2}\right)$. This was also the latitude where large outliers in krill density were with the $\log$ of krill abundance $\left(b_{1}=0.64\right.$, SE 0.12, $\mathrm{p}<0.001)$ while no relationship was present for the aerial sighting survey $\left(b_{1}=-0.08\right.$, SE $\left.0.12, \mathrm{p}=0.5\right)$. The relationship between whale density (given presence) and log krill abundance was weaker than that for presence and not significant in the full model (Table 4). However, in the ship-only model whale density was significantly explained by the log krill abundance $(\mathrm{p}=0.03)$.

Other than krill, the models for both survey platforms exhibited significant responses to the same variables. This included longitude, slope, and sea surface temperature. Depth was not an important variable in models explaining either presence or density of large whales on the shelf of West Greenland. The consis- 


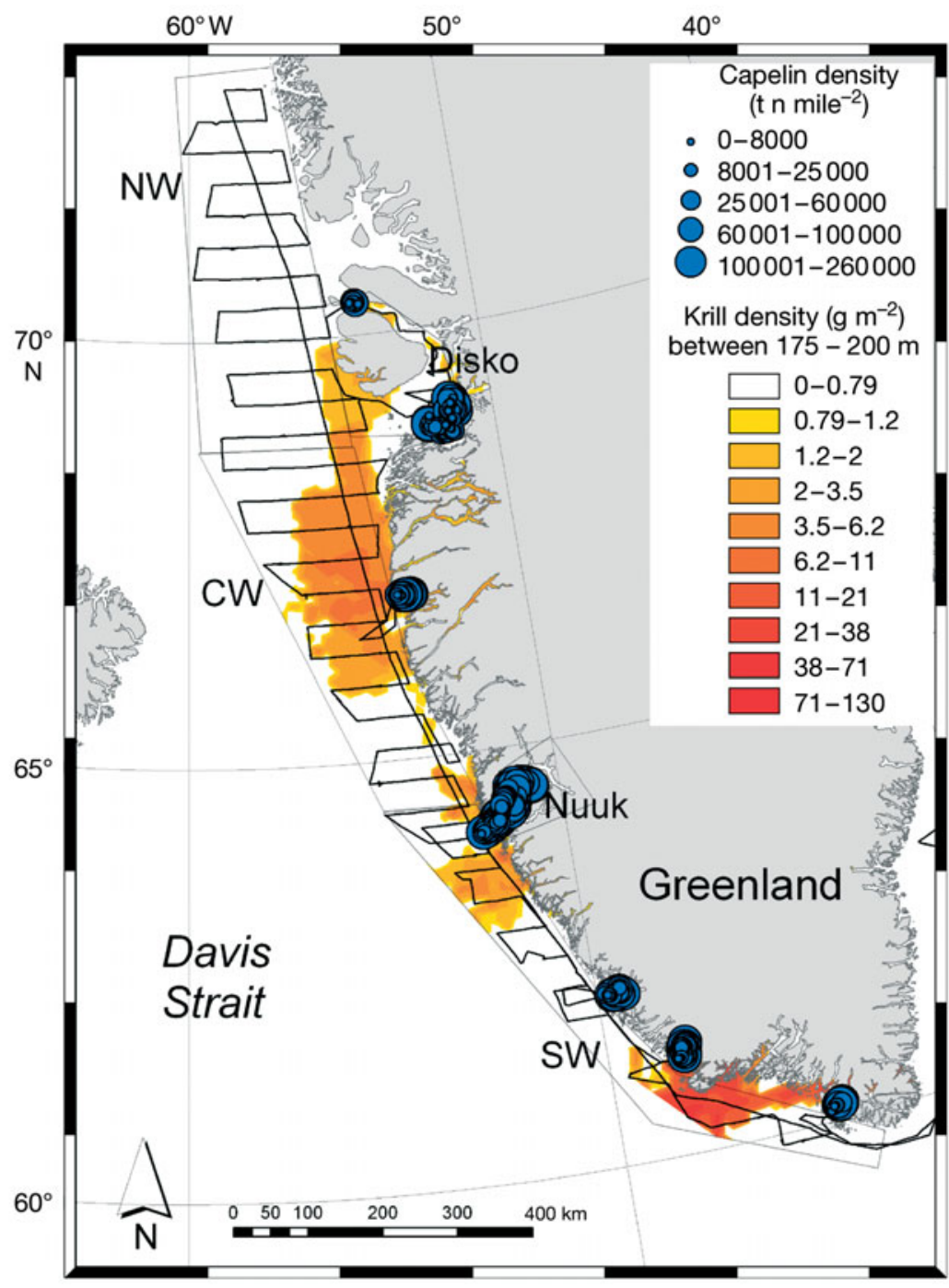

Fig. 5. Mallotus villosus, Meganyctiphanes norvegica and Thysanoessa sp. Trackline of continuous ship acoustic effort together with detections of capelin and concentrations of krill $>0.8 \mathrm{~g} \mathrm{~m}^{-2}$ (kriged density between 175 and $200 \mathrm{~m}$ ). Strata for total krill biomass calculations are labeled NW (Northwest), CW (Central West), SW (Southwest), Disko and Nuuk tency between the significance of all other ecological variables across the 2 surveys suggested that the krill covariate was significant for the ship platform due to temporal continuity with whale sightings and acoustic data collection (used to determine krill biomass).

Response curves for all species combined demonstrate a nearly linear relationship between the presence of one or more whales at a given location and the biomass of krill in the area (Fig. 8). Response curves also suggested whale presence was inversely correlated to latitude and longitude, i.e. more whales were sighted in South Greenland (lower latitudes) and farther from shore (larger longitudes) (Fig. 8). In the model for whale density (given presence) there was a positive relationship to longitude, where larger groups were located farther east (or closer to the coast) (Fig. 9). Models were also developed independently for each species. Associations with log krill abundance were consistent across species despite much smaller sample sizes. However, the low number of sightings for each species when factoring in survey platform limited statistically robust conclusions.

The log odds-ratio plot for the presence of whales in West Greenland with respect to depth specific water column biomass of krill $\left(\mathrm{g} \mathrm{m}^{-2}\right)$ demonstrated that krill water column biomass at depths of 150 to $175 \mathrm{~m}$ were most predictive of whale presence based on data from the ship survey (Fig. 10). The relationship was similar for group size. Depths below $150 \mathrm{~m}$ continued to be predictive of whale presence on the ship up to $300 \mathrm{~m}$. Krill water column daytime biomass at depths above $100 \mathrm{~m}$ had no significant correlation to whale presence.

\section{DISCUSSION}

\section{Data, covariates, and modeling}

Our results suggest the most important variable for determining the presence of large baleen whales on the West Greenland summer feeding ground is krill biomass. This relationship, however, was only significant when there was close spatio-temporal proximity in whale sightings and measurements of krill. This is very likely due to the dynamic nature of krill on the shelf, where even a short temporal lag (on the order of days) weakens the association. This provides indirect evidence that the time-scale of cohesion for a krill patch is no greater than the several day asynchrony between the aerial and ship surveys. These results also imply that caution should be used in quantifying relationships between marine predators and their dynamic or ephemeral prey when observations on both are not synchronous.

There was a common effect of other covariates across survey types (slope, sea surface temperature), suggesting that other, less dynamic ecological correlates such as slope or longitude (distance from the coast) are similarly good in explaining whale presence 


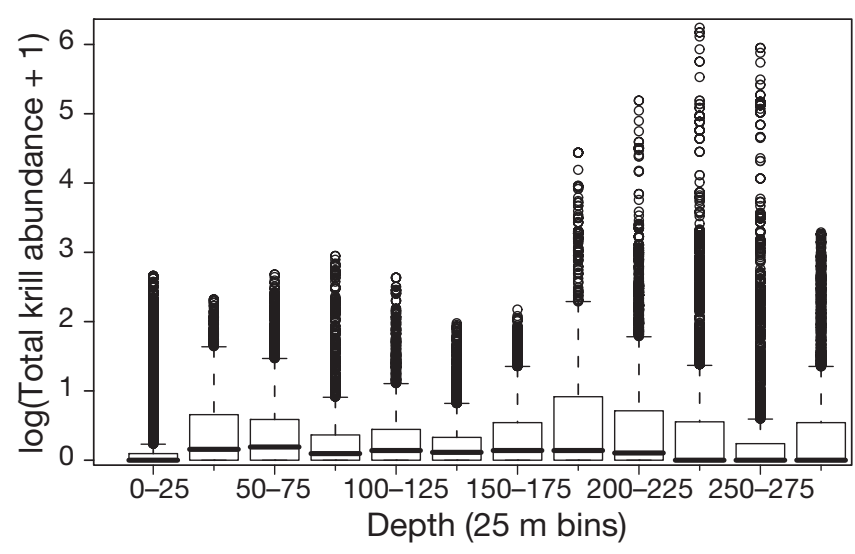

Fig. 6. Meganyctiphanes norvegica and Thysanoessa sp. Box plot of log krill water column biomass by depth bin in West Greenland from ship survey. Horizontal line indicates median response; bottom and top of box show 25 and 75 percentiles respectively. Open circles beyond interquartile range (dashed line with horizontal bars) are outliers

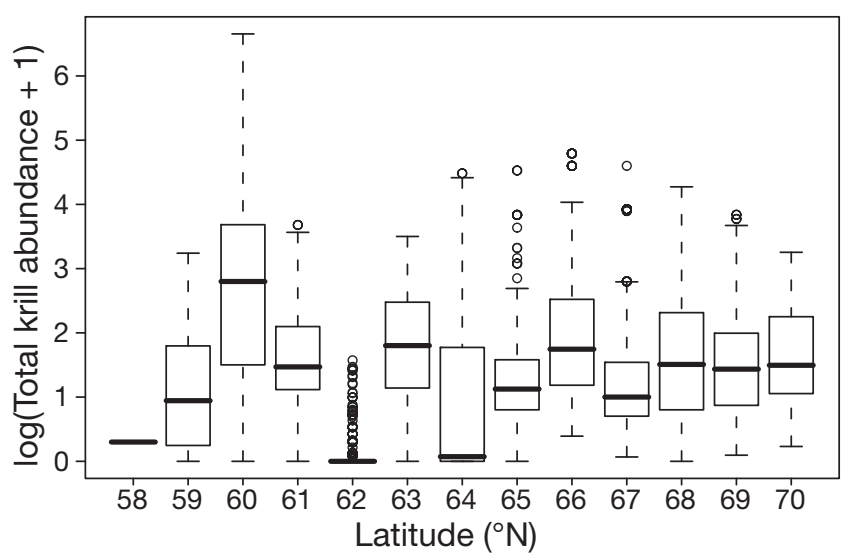

Fig. 7. Meganyctiphanes norvegica and Thysanoessa sp. Box plot of log krill water column biomass by latitude in West Greenland from the ship survey, where all measurements for a given degree of latitude were pooled. See Fig. 6 for explanation of box plots

regardless of a ship or plane survey platform. It is also important to consider the effect of kriging prey abundance. Kriging introduces measurement error and fills in space where the covariate was not measured directly, as is often the case with measures of prey density or biomass. Kriging is best performed if the spatial interpolation occurs at a smaller scale than the spatial extent of the prey patch.

Although models strongly indicated that large baleen whales are located in areas with high water column biomass concentrations of krill, models of density (or group size) did not. This may be due to the fact most group sizes were between 1 and 3 individuals. The distribution of values was therefore very narrow and it was difficult to identify significant relationships with density. The GAM functions used in the present study
Table 2. Total integrated water column krill biomass (kg) in 5 strata based on Heide-Jørgensen et al. (2007b). NW: Northwest; CW: Central West; SW: Southwest. See Fig. 5 for strata

\begin{tabular}{|lccc|}
\hline Strata & $\begin{array}{c}\text { Strata } \\
\text { area }\left(\mathrm{km}^{2}\right)\end{array}$ & $\begin{array}{c}\text { Biomass of } \\
\text { krill }(\mathrm{kg})\end{array}$ & $\mathrm{CV}$ \\
\hline NW & 82518 & $2.1 \times 10^{8}$ & 0.11 \\
$\mathrm{CW}$ & 72342 & $3.5 \times 10^{8}$ & 0.13 \\
SW & 51684 & $6.4 \times 10^{8}$ & 0.22 \\
Disko & 15780 & $1.2 \times 10^{8}$ & 0.12 \\
Nuuk & 2843 & $3.2 \times 10^{7}$ & 0.24 \\
Total & 225167 & $1.3 \times 10^{9}$ & 0.11 \\
\hline
\end{tabular}

Table 3. Table of parameter estimates for a logistic regression of whale presence with respect to a suite of variables. The log.abundance variable represents the integrated krill abundance from 0 to $300 \mathrm{~m}$. Res.long: residual longitude after regression of longitude on latitude; Depth: depth in $\mathrm{m}_{\text {; }}$ SST: sea surface temperature in ${ }^{\circ} C_{i}$ Slope: seafloor slope in percent rise

\begin{tabular}{|lrrrc|}
\hline & Estimate & SE & Z-statistic & p-value \\
\hline Intercept & 9.40 & 7.11 & 1.74 & 0.1865 \\
Latitude & -0.17 & 0.12 & 2.15 & 0.1422 \\
Latitude & 0.06 & 0.03 & 4.95 & 0.0262 \\
Res.long & -0.46 & 0.09 & 24.86 & $<0.001$ \\
Depth & -0.001 & 0.00 & 4.54 & 0.0330 \\
Log. & 0.003 & 0.12 & 0.00 & 0.9788 \\
$\quad$ abundance & & & & \\
SST & -0.49 & 0.16 & 9.71 & 0.001 \\
Slope & 0.14 & 0.03 & 26.51 & $<0.001$ \\
Factor(Survey & -2.15 & 0.50 & 18.68 & $<0.001$ \\
$\quad$ Type)ship & & & & \\
Log. abundance: & 0.59 & 0.16 & 13.92 & $<0.001$ \\
$\quad$ factor(Survey & & & & \\
$\quad$ Type)ship & & & & \\
\hline
\end{tabular}

Table 4. Table of parameter estimates for a Poisson regression of whale group size given presence with respect to a suite of variables. The log.abundance variable represents the integrated krill abundance from 0 to $300 \mathrm{~m}$. See Table 3 for other definitions

\begin{tabular}{|lrrcr|}
\hline & Estimate & SE & Z-statistic & p-value \\
\hline Intercept & 13.20 & 5.35 & 6.09 & 0.014 \\
Latitude & -0.18 & 0.10 & 3.65 & 0.056 \\
Res.long & -0.07 & 0.14 & 0.28 & 0.594 \\
Depth & 0.00 & 0.00 & 0.54 & 0.464 \\
Log.abundance & 0.00 & 0.20 & 0.00 & 0.991 \\
SST & -0.03 & 0.39 & 0.01 & 0.937 \\
Slope & -0.03 & 0.03 & 0.73 & 0.393 \\
Factor(Survey & -1.26 & 0.70 & 3.27 & 0.071 \\
$\quad$ Type)ship & & & & \\
Log. abundance: & 0.08 & 0.29 & 0.08 & 0.778 \\
$\quad$ factor(Survey & & & & \\
$\quad$ Type)ship & & & & \\
\hline
\end{tabular}



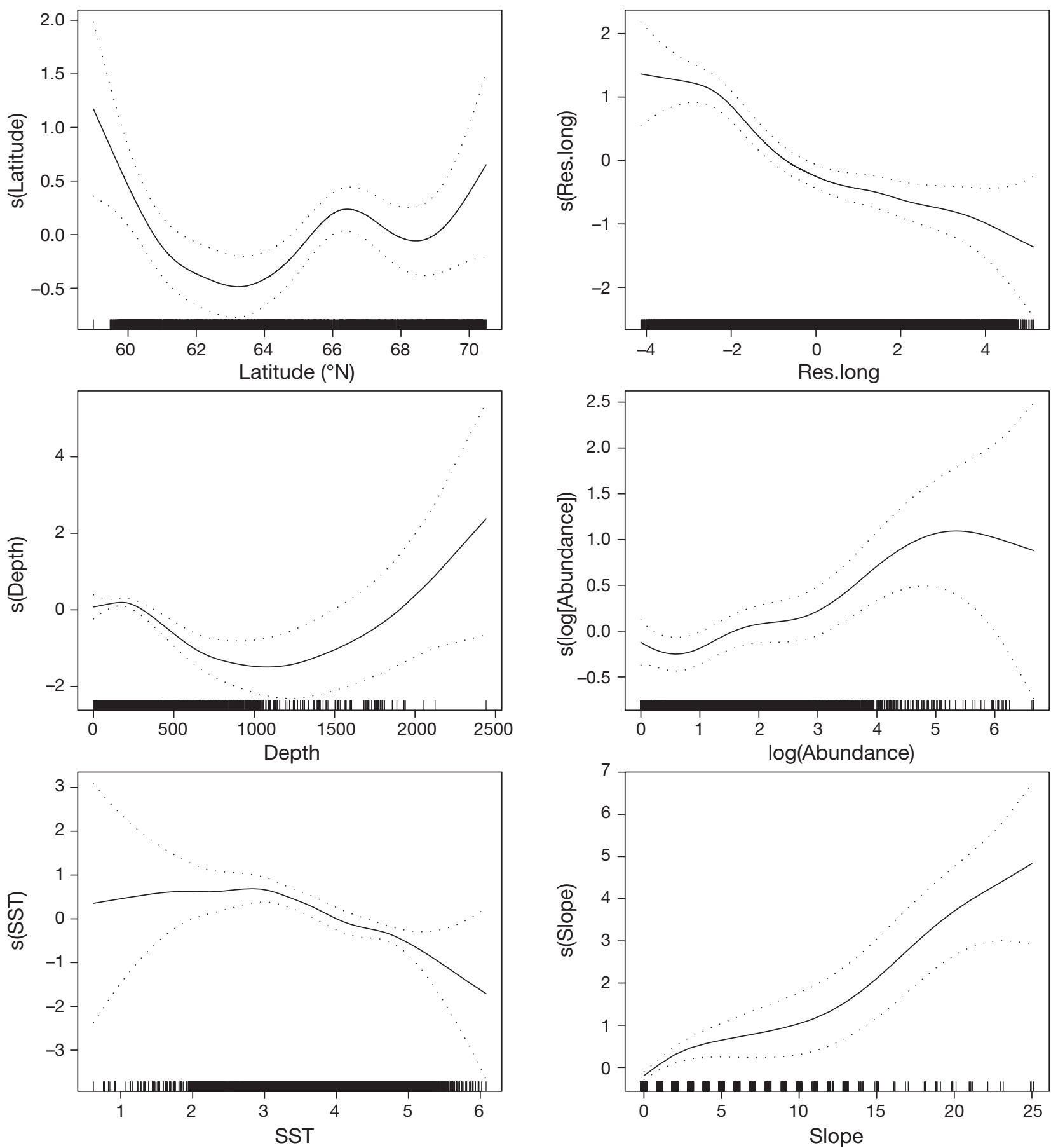

Fig. 8. Balaenoptera physalus, Megaptera novaeangliae, B. acutorostrata, and B. borealis. Generalized Additive Model (GAM) response curves for whale presence/absence and physical-biological variables using $2 \mathrm{~km}$ survey transects made during 2005 in West Greenland. These partial plots control for other predictions in the relationships shown. They are the result of back-fitting the algorithm used by the R-function GAM to calculate the additive contribution of each variable using nonparametric smoothing methods. Dashed lines represent $95 \%$ confidence intervals for the fitted relationship

do not carry unrealistic assumptions of a normal distribution of errors or linear response shapes and are therefore appropriate for the wide range of continuous and categorical covariates used in this study. This ap- proach is used widely for species distribution models and has proven to be robust to understanding species presence and absence patterns (Elith et al. 2006, Ferguson et al. 2006, Redfern et al. 2006, Wisz et al. 2008). 

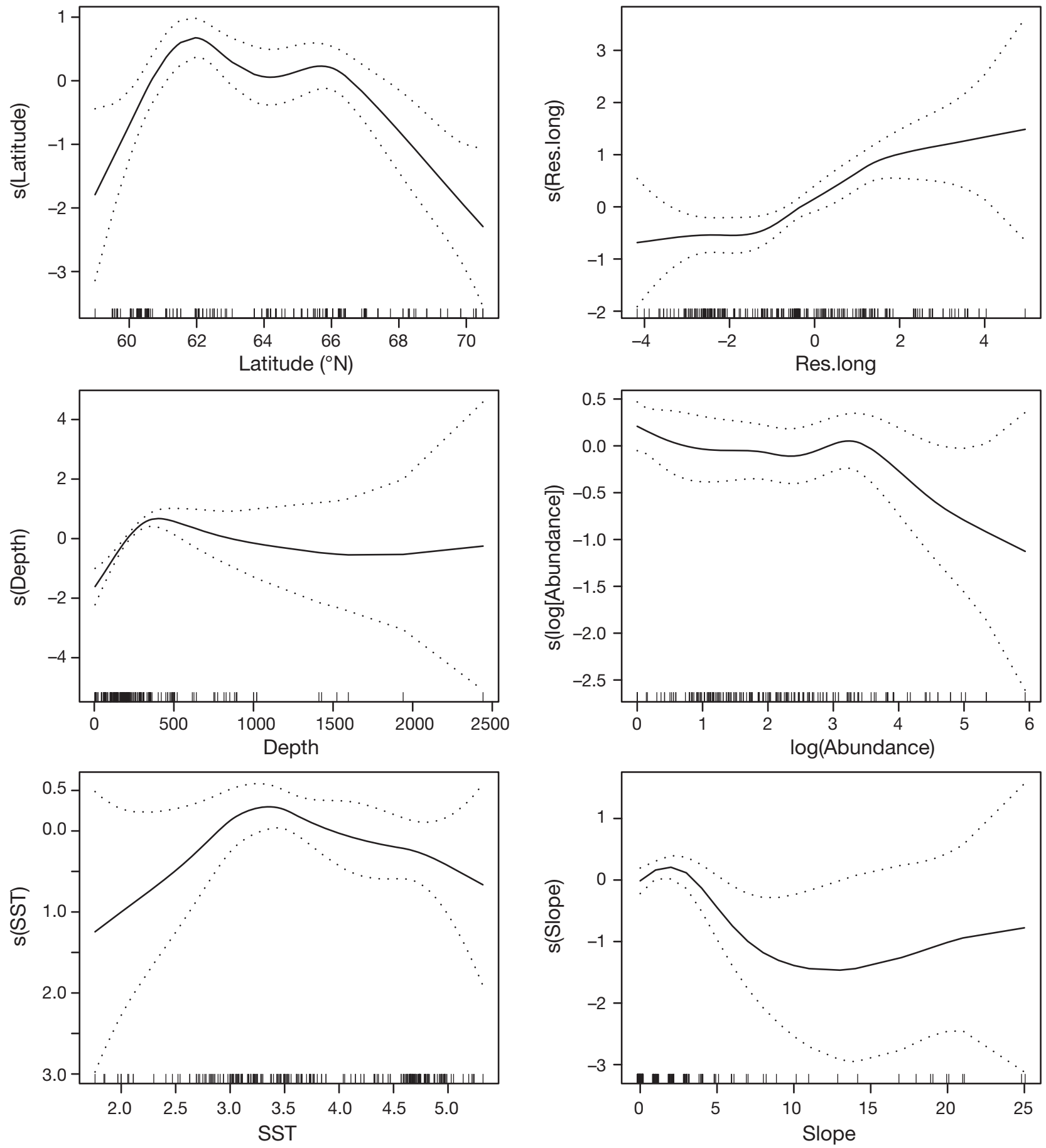

Fig. 9. Balaenoptera physalus, Megaptera novaeangliae, B. acutorostrata, and B. borealis. Generalized Additive Model (GAM) response curves for whale density given presence and physical-biological variables using $2 \mathrm{~km}$ survey transects made during 2005 in West Greenland

\section{Relationships between krill and baleen whales}

A striking relationship was apparent between the depth-specific krill water column biomass and the presence of whales in the ship survey data on the shelf. The biomass of krill at a given depth became highly predictive of whale presence at depths of $150 \mathrm{~m}$ or greater (and most predictive at 150 to $175 \mathrm{~m}$ ), as demonstrated by the large log-odds ratio (Fig. 10). There was no relationship between the presence of whales and the abundance of krill in shallow depths $<100 \mathrm{~m}$, suggesting surface aggregations of krill do not 


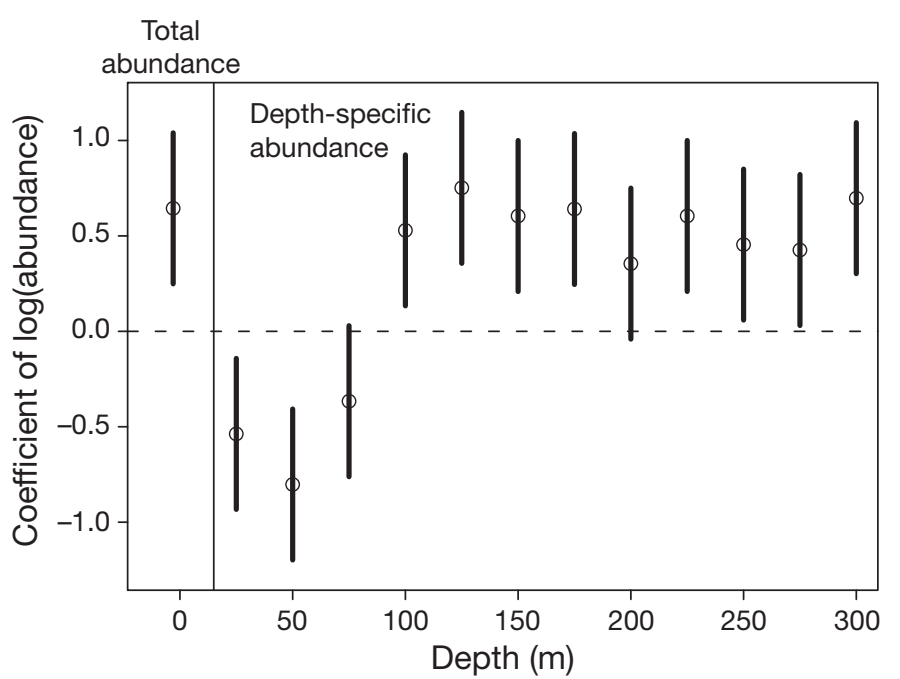

Fig. 10. Balaenoptera physalus, Megaptera novaeangliae, B. acutorostrata, $B$. borealis. Log odds-ratio coefficient with respect to depth for the probability of sighting a whale on the ship survey in West Greenland with respect to depth-specific water column biomass of krill Meganyctiphanes norvegica and Thysanoessa sp. $\left(\mathrm{g} \mathrm{m}^{-2}\right)$. The ratio for total water column biomass of krill is shown on the left

determine where whales forage offshore on the West Greenlandic shelf. This follows well with the general patterns of krill density, where the largest aggregations of biomass appear below $175 \mathrm{~m}$. It is interesting that the most predictive depth was not the peak in mean krill water column biomass (225 to $250 \mathrm{~m}$ ). Krill in West Greenland likely make diurnal migrations similar to other Arctic zooplankton (Berge et al. 2009), and the depth at which baleen whales can reliably find large patches of krill likely varies depending on the time of day.

These results suggest there is a threshold depth at or below which it is energetically optimal for baleen whales to forage on krill. This appears to be $>150 \mathrm{~m}$ in West Greenland and follows well with other studies that have suggested thresholds for optimal foraging in baleen whales (Piatt \& Methven 1992). Extensive associations have been made between top marine predators and krill in other ecosystems (Ainley et al. 2006, Nicol et al. 2008, Ribic et al. 2008, Friedlaender et al. 2008). It has been shown that humpback whales target krill in the upper $100 \mathrm{~m}$ of the water column in the Antarctic (Fig. 8, Friedlaender et al. 2006, 2008). It is possible that whales in West Greenland target krill in shallower depths during nighttime.

The clear peak in krill density in South Greenland at $60^{\circ}$ to $61^{\circ} \mathrm{N}$ is likely the reason for the high rates of occurrence of large whales in this area (Fig. 3, 4 \& 5). This region was associated with large outliers in krill density that were orders of magnitude larger than the mean (several measures of krill over $500 \mathrm{~g} \mathrm{~m}^{-2}$ ).
Another focal area used by whales farther north, at approximately $66^{\circ} \mathrm{N}$, was also associated with elevated mean densities of krill (Fig. 5); however, these krill densities were not as extreme as those in South Greenland. The aggregations of whales found in this area were primarily fin whales.

It is plausible that feeding conditions set up by physical variables in 2005 influenced the distribution and abundance of baleen whales on the West Greenland banks. June 2005 had some of the warmest temperatures (and highest salinities) measured in West Greenland during the past $50 \mathrm{yr}$, and an attractive hypothesis is that krill were advected to West Greenland with warmer water originating in the North Atlantic in 2005. What remains to be understood is whether the occurrence of krill in West Greenland in 2005 was part of an unusual large-scale advection event driven by specific oceanographic conditions or if krill are found regularly on the West Greenland banks in similar densities.

The models suggest that the relationship between whales and krill is significant when there is a very precise temporal match between data sets, and it would be useful to document how dynamic krill abundance is on the shelf of West Greenland. Unfortunately, there is little historical information available. Significant krill concentrations were detected on surveys in 1963 and 1964 in West Greenland (Smidt 1971); however, methods and coverage are not comparable to our study. Pedersen \& Smidt (2000) presented a time series from standardized net hauls on Fyllas Bank between 1950 and 1984 but failed to detect any trends in krill abundance.

Unusually large group sizes of fin and humpback (Fig. 3) whales were found in the present study. This was surprising because surveys conducted regularly between 1983 and 2008 in West Greenland have shown that these whales occur in small groups of less than 5 individuals (Larsen \& Hammond 2004, Witting \& Kingsley 2005, Heide-Jørgensen et al. 2008). However, in the present study and consequent surveys in 2007 for fin whales (Greenland Institute of Natural Resources unpubl. data) these species were detected in unprecedented large groups of $>50$. It is possible these large group sizes are associated with unusually high abundances of krill in West Greenland. Sei whales feed almost exclusively on krill and have been infrequent visitors on the West Greenland banks for the past several decades (Kapel 1979) yet were detected frequently in our study ( $\mathrm{n}=17$ sightings).

The estimates of krill biomass in this study should be considered indices rather than absolute estimates due to the potential for the signal-to-noise ratio (SNR) to wane at deeper depths. This was not measured and it is possible that krill abundance is underestimated at deeper depths. This would, however, not have any 
impact on the results presented here both because krill biomass is already shown to be higher at deeper depths and because foraging dives of large baleen whales are costly and generally limited to the depths $(<300 \mathrm{~m})$ investigated in our models.

\section{Other potential prey species}

Capelin are also an important and predicable prey resource for baleen whales in Greenland. Capelin occupy a central position in the trophic web of cold water ecosystems in the Atlantic and have attracted substantial scientific interest both due to their ecological importance and to their substantial value for both large-scale commercial fisheries and small-scale traditional use in Inuit culture (Rose 2005). This survey was conducted late in the summer when capelin were absent on the banks, having moved offshore with the exception of the highly dense coastal spawning aggregations. Capelin were excluded from the GAM analysis because of the highly discontinuous and coastal nature of their distribution (Fig. 5).

Spawning capelin are frequently targeted by minke and humpback whales in coastal regions like Disko Bay and Vaigat. Visual observations of feeding whales along the coast together with satellite tracking studies demonstrate that these aggregations are important during summer (Heide-Jørgensen \& Laidre 2007); however, they are generally only targeted by a low number of individuals. Recent abundance estimates suggest approximately 1200 humpback whales occupy West Greenland in summer (Heide-Jørgensen et al. 2008) and most of these individuals are found outside of the coastal fjords on the offshore banks. Thus, it is expected feeding conditions out to the $200 \mathrm{~m}$ depth contour, such as krill densities, are more important on a population level than coastal capelin resources.

\section{Species-specific foraging patterns}

Large whales that arrive in West Greenland from wintering grounds in the Atlantic Ocean have speciesspecific feeding strategies during summer. In some cases, species have adopted multiple strategies for obtaining resources in West Greenland. Among those is the humpback whale. Low numbers of humpback whales (single individuals or groups of 2 to 3) are frequently and predictably found inshore feeding on capelin in Disko Bay, Vaigat, and Nuuk fjord in waters $<25 \mathrm{~m}$ deep and $<50 \mathrm{~m}$ from the shore. Humpback whales clearly rely on capelin resources; however, densities are low and the resource is patchy. Consequently, the majority of humpback whales foraging in
West Greenland target offshore concentrations of prey such as krill or sandeels. Although krill are spread out over a much larger geographic area, the dense patches and high biomass can support a large biomass of foraging whales provided high density patches can be located. Locating dense aggregations of krill may require a higher degree of cooperation among whales, possibly explaining larger offshore aggregations.

Fin whales, like humpback whales, have a duel strategy of feeding on coastal capelin concentrations and offshore krill patches (Kapel 1979). Fin whales have been shown to utilize an energetically expensive strategy of lunge feeding at depth (see Croll et al. 2001, 2005, Simard et al. 2002) upon encounters with suitable densities of prey (Acevedo-Gutierrez et al. 2002, Goldbogen et al. 2006, 2007). In the present study, fin whales were primarily found in the area between the Store and Lille Hellefiske Banks and on the western edge of Store Hellefiske Bank. These are the most productive sites on the banks of West Greenland (StorrPaulsen et al. 2004, Pedersen et al. 2005, Heide-Jørgensen et al. 2007a). Observations of fin whales in these areas together with high prey densities support conclusions from previous satellite tracking studies that fin whales move into these areas to feed (HeideJørgensen et al. 2003).

Minke whale distribution was the most irregular in this study (Fig. 2c). Sightings were made along the entire coast with few detectable patterns other than a slightly higher density in South Greenland. This region is known to be an important area for the species (Laidre et al. 2009). Minke whales are the most icthyophagous of the Balaenoptera and target primarily capelin and sandeels, reported both in studies of stomach contents of harvested whales caught in Greenland (Kapel 1979) and in other areas of the Atlantic (Macleod et al. 2004). They do, however, occasionally feed on krill in West Greenland, yet the importance of krill in their diet is unknown.

Sei whales occurred in low abundance on both the aerial and ship surveys. They have been proposed to occur in West Greenland during periods with an influx of warm water (Kapel 1979, Neve 2000). This species feeds almost exclusively on krill (Kapel 1979). Although sample sizes were too small to make conclusive associations between sei whale distribution and krill densities, the focal area of sightings corresponded well to the areas with the highest densities of krill and where the peak aggregations occurred (Fig. 2).

\section{CONCLUSIONS}

On multiple spatial scales, all foraging top predators must investigate and exploit a network of feeding sites 
in order to meet energetic demands (Stevick et al. 2008). In a highly variable environment such as West Greenland, this requires adopting different foraging strategies, exploiting diverse prey resources, and likely utilizing different levels of cooperation (or isolation) between individuals to succeed. All of these may be functions of mobility, the cost of transport, and the foraging success resulting from different strategies.

In summary, large whales in West Greenland clearly aggregate in areas with high concentrations of krill. This is necessary to meet energetic demands during the summer feeding period. West Greenland is a dynamic ecosystem, and the availability of prey is patchy and variable with transitory optimal physical conditions that set up the oceanographic and biological conditions necessary for recruitment of forage. Given the importance of Arctic shelf regions to predators seeking abundant resources in summer, there is potential for dramatic ecosystem shifts given the observed reductions in sea ice cover, ice thickness, extent, and duration, changes in current patterns and temperatures in these areas due to climate change (Carmack \& Wassmann 2006).

Acknowledgements. The surveys were funded by the Greenland Institute of Natural Resources and the Greenland Home Rule government. Thanks to the many observers who collected data on both survey platforms. Four anonymous reviewers and comments from D. Demer, S. T. Jonsson, and E. Gurarie improved the manuscript.

\section{LITERATURE CITED}

Acevedo-Gutierrez A, Croll DA, Tershy BR (2002) High feeding costs limit dive time in the largest whales. J Exp Biol 205:1747-1753

Ainley DG, Ballard G, Dugger KM (2006) Competition among penguins and cetaceans reveal trophic cascades in the Western Ross Sea, Antarctica. Ecology 87:2080-2093

Berge J, Cottier F, Last KS, Varpe $\varnothing$ and others (2009) Diel vertical migration of Arctic zooplankton during the polar night. Biol Lett 5:69-72

Carmack E, Wassmann P (2006) Food webs and physicalbiological coupling on pan-Arctic shelves: unifying concepts and comprehensive perspectives. Prog Oceanogr 71: $446-477$

CCAMLR (2005) Report of the first meeting of the subgroup on acoustic survey and analysis methods. SC-CAMLRXXIV/BG/3. CCAMLR, Hobart

> Charnov EL (1976) Optimal foraging, the marginal value theorem. Theor Popul Biol 9:129-136

Conti SG, Demer DA (2006) Improved parameterization of the SDWBA for estimating krill target strength. ICES J Mar Sci 63:928-935

> Conti SG, Demer DA, Soule MA, Conti JHE (2005a) An improved multiple-frequency method for measuring in situ target strengths. ICES J Mar Sci 62:1636-1646

Conti SG, Demer DA, Brierley AS (2005b) Broad-bandwith, sound scattering, and absorption from krill (Meganyctiphanes norvegica), mysids (Praunus flexuosus and
Neomysis integer), and shrimp (Crangon crangon). ICES J Mar Sci 62:956-965

Croll DA, Acevedo-Gutierrez A, Tershy BR, Urban-Ramirez J (2001) The diving behavior of blue and fin whales: Is dive duration shorter than expected based on oxygen stores? Comp Biochem Physiol 129A:797-809

Croll DA, Marinovic B, Benson S, Chavez FP, Black N, Ternullo R, Tershy BR (2005) From wind to whales: trophic links in a coastal upwelling system. Mar Ecol Prog Ser 289: $117-130$

> Demer DA, Hewitt RP (1995) Bias in acoustic biomass estimates of Euphausia superba due to diel vertical migration. Deep-Sea Res I 42:455-475

- Elith J, Graham CH, Anderson RP, Dudik M and others (2006) Novel methods improve prediction of species' distributions from occurrence data. Ecography 29: $129-151$

> Ferguson MC, Barlow J, Fiedler P, Reilly SB, Gerrodette T (2006) Spatial models of delphinid (family Delphinidae) encounter rate and group size in the eastern tropical Pacific Ocean. Ecol Model 193:645-662

Friedlaender AS, Halpin PH, Qian SS, Wiebe PH, Thiele D, Read AJ (2006) Whale distribution in relation to prey abundance and oceanographic processes in the Western Antarctic Peninsula shelf waters. Mar Ecol Prog Ser 317: $297-310$

Friedlaender AS, Fraser WR, Patterson D, Qian SS, Halpin PN (2008) The effects of prey demography on humpback whale (Megaptera novaengliae) abundance around Anvers Island, Antarctica. Polar Biol 31:1217-1224

Goldbogen JA, Calambokidis J, Shadwick RE, Oleson EM, McDonald MA, Hildebrand JA (2006) Kinematics of foraging dives and lunge-feeding in fin whales. J Exp Biol 209: 1231-1244

Goldbogen JA, Pyenson ND, Shadwick RE (2007) Big gulps require high drag for fin whale lunge feeding. Mar Ecol Prog Ser 349:289-301

Heagerty PJ, Lumley T (2000) Window subsampling of estimating functions with application to regression models. J Am Stat Assoc 95:197-211

Heide-Jørgensen MP, Laidre KL (2007) Autumn space-use patterns of humpback whales (Megaptera novaeangliae) in West Greenland. J Cetacean Res Manag 9:121-126

Heide-Jørgensen MP, Witting L, Jensen MV (2003) Inshoreoffshore movements of two satellite-tagged fin whales (Balaenoptera physalus) off West Greenland. J Cetacean Res Manag 5:241-245

Heide-Jørgensen MP, Laidre KL, Logsdon ML, Nielsen TG (2007a) Springtime coupling between phytoplankton, sea ice and sea temperature in Disko Bay, West Greenland. Prog Oceanogr 73:79-95

> Heide-Jørgensen MP, Simon MJ, Laidre KL (2007b) Estimates of large whale abundance in Greenland in September 2005. J Cetacean Res Manag 9:95-104

Heide-Jørgensen MP, Borchers DL, Witting L, Simon MJ, Laidre KL, Rosing-Asvid A, Pike D (2008) Estimates of large whale abundance in West Greenland waters from an aerial survey in 2005. J Cetacean Res Manag 10: $119-129$

Hewitt RP, Demer DA, Emery JH (2003) An eight year cycle in krill biomass density inferred from acoustic surveys conducted in the vicinity of the South Shetland Islands during the austral summers of 1991/1992 through 2001-2002. Aquat Living Resour 16:205-213

Jakobsson M, Macnab R, Mayer M, Anderson R and others (2008) An improved bathymetric portrayal of the Arctic Ocean: implications for ocean modeling and geological, 
geophysical and oceanographic analyses. Geophys Res Lett 35:L07602, doi:10.1029/2008GL033520

Kapel FO (1979) Exploitation of large whales in West Greenland in the twentieth century. Rep Int Whaling Comm 29: 197-214

Laidre KL, Heide-Jørgensen MP, Nyland J, Mosbech A, Boertmann D (2008) Latitudinal gradients in sea ice and primary production determine Arctic seabird colony size in Greenland. Proc Biol Sci 275:2695-2702

Laidre KL, Heagerty P, Heide-Jørgensen MP, Witting L, Simon M (2009) Sexual segregation of common minke whales (Balaenoptera acutorostrata) and sex ratio of catches in Greenland. ICES J Mar Sci 66:2253-2266

Larsen F, Hammond PS (2004) Distribution and abundance of West Greenland humpback whales (Megaptera novaeangliae). J Zool 263:343-358

Macleod K, Fairbairns R, Gill A, Fairbairns B, Gordon J, BlairMyers C, Parsons ECM (2004) Seasonal distribution of minke whales Balaenoptera acutorostrata in relation to physiography and prey off the Isle of Mull, Scotland. Mar Ecol Prog Ser 277:263-274

Madureira LSP, Ward P, Atkinson A (1993) Differences in backscattering strength determined at 120 and $38 \mathrm{kHz}$ for three species of Antarctic macroplankton. Mar Ecol Prog Ser 93:17-24

Myers PG, Kulan N, Ribergaard MH (2007) Irminger water variability in the West Greenland Current. Geophys Res Lett 34:L17601, doi:10.1029/2007GL030419

Neve PB (2000) The diet of the minke whale in Greenland - a short review. NAMMCO Sci Publ 2:92-96

> Nicol S, Clarke J, Romaine SJ, Kawaguchi S, Williams G, Hosie GW (2008) Krill (Euphausia superba) abundance and Adélie penguin (Pygoscelis adeliae) breeding performance in the waters off the Béchervaise Island colony, East Antarctica in 2 years with contrasting ecological conditions. Deep-Sea Res II 55:540-557

> Onsrud MSR, Kaartvedt S (1998) Diel vertical migration of the krill Meganyctiphanes norvegica in relation to physical environment, food and predators. Mar Ecol Prog Ser 171: 209-219

> Pedersen SA, Smidt ELB (2000) Zooplankton distribution and abundance in West Greenland waters, 1950-1984. J Northwest Atl Fish Sci 26:45-102

Pedersen SA, Ribergaard MH, Simonsen CS (2005) Microand mesozooplankton in Southwest Greenland waters in relation to environmental factors. J Mar Syst 56:85-112

Piatt JF, Methven DA (1992) Threshold foraging behavior of baleen whales. Mar Ecol Prog Ser 84:205-210 s

Editorial responsibility: Hans Heinrich Janssen, Oldendorf/Luhe, Germany
Pople AR, Phinn SR, Menke N, Grigg GC, Possingham HP, McAlpine C (2007) Spatial patterns of kangaroo density across the South Australian pastoral zone over 26 years: aggregation during drought and suggestions of long distance movement. J Appl Ecol 44:1068-1079

R Development Core Team (2009). R: a language and environment for statistical computing. R Foundation for Statistical Computing, Vienna; www.R-project.org.

Redfern JV, Ferguson MC, Becker EA, Hyrenbach KD and others (2006) Techniques for cetacean-habitat modeling. Mar Ecol Prog Ser 310:271-295

Reiss CS, Cossio AM, Loeb V, Demer DA (2008) Variations in the biomass of Antarctic krill (Euphausia superba) around the South Shetland Islands, 1996-2006. ICES J Mar Sci 65:497-508

> Ribic CA, Chapman E, Fraser WR, Lawson GL, Wiebe PH (2008) Top predators in relation to bathymetry, ice and krill during austral winter in Marguerite Bay, Antarctica. Deep-Sea Res II 55:485-499

> Rose GA (2005) Capelin (Mallotus villosus) distribution and climate: a sea 'canary' for marine ecosystem change. ICES J Mar Sci 62:1524-1530

> Schoener TW (1971) Theory of feeding strategies. Annu Rev Ecol Syst 2:369-404

> Simard Y, Lavoie D, Saucier FJ (2002) Channel head dynamics: capelin (Mallotus villosus) aggregation in the tidally driven upwelling system of the Saguenay St. Lawrence Marine Park's whale feeding ground. Can J Fish Aquat Sci 59:197-210

Smidt ELB (1971) Summary report of the ICNAF NORWESTLANT surveys, 1963. Int Comm Northwest Atl Fish Redb Part III:275-295

Stevick PT, Incze LS, Kraus SD, Rosen S, Wolff N, Baukus A (2008) Trophic relationships and oceanography on and around a small offshore bank. Mar Ecol Prog Ser 363:15-28

> Storr-Paulsen M, Wieland K, Hovgård H, Rätz HJ (2004) Stock structure of Atlantic cod (Gadus morhua) in West Greenland waters: implications of transport and origin. ICES J Mar Sci 61:972-982

- Wisz MS, Tamstorf MP, Madsen J, Jespersen M (2008) Where might the western Svalbard tundra be vulnerable to pinkfooted goose (Anser brachyrhynchus) population expansion? Clues from species distribution models. Divers Distrib 14:26-37

Witting L, Kingsley M (2005) Abundance of marine mammals off West Greenland, 2002-2004. International Whaling Commission Scientific Committee Meeting document SC/ 57/AWMP3. Available from www.iwcoffice.org

Submitted: February 2, 2009; Accepted: November 16, 2009 Proofs received from author(s): February 16, 2010 